\section{Ocular responses after intravenous lidocaine}

\section{To the Editor:}

We read with interest the review of the physiological and anaesthetic implications of increased intraocular pressure (IOP).'

We wish to further emphasize the role of intravenous lidocaine in mitigating or preventing the systemic and ocular reactions and especially the acute increase in IOP associated with laryngoscopy and tracheal intubation. ${ }^{2}$ The mechanisms of elevation of IOP after laryngoscopy and after succinylcholine administration are different, so pretreatment with a small dose of gallamine or d-tubocurarine will not attenuate the increase in IOP caused by tracheal intubation itself. The rise in IOP is, in fact, caused by sympathetically mediated vasoconstriction generating increased venous retum and a sudden rise in central venous pressure.

The administration of $2 \mathrm{mg} \cdot \mathrm{kg}^{-1}$ lidocaine IV two minutes prior to intubation has atcenuated significantly the rise in heart rate and lowered the incidence of such local laryngeal reflexes as cough and breath-holding, and of ocular responses such as pupillary dilatation or lacrimation. IV lidocaine caused a significant reduction of IOP prior to tracheal intubation, compared to saline given in a control group, as well as significant suppression of the increase in IOP following laryngoscopy and intubation.

We advocate the routine use of intravenous lidocaine prior to tracheal intubation in patients suffering from glaucomatous or lacerated eye, and in other urgent ophthalmic operations.

B. Drenger MD

M. Gertel MD FRCPC

J. Pe'er MD

Department of Ophthalmology

Hadassah University Hospital

P.O.B. 12000

11-91 120 Jerusalem

Israel

REFERENCES

1 Cunningham AJ, Barry P. Intraocular pressure physiology and implications for anaesthetic management. Can Anaesth Soc J 1986; 33: 195-208.

2 Drenger $B$, Pe'er I, RenEzra D, Katznelson $R$, Davidson $J T$. The influence of intravenous lidocaine on the increased intrancular pressure induced by tracheal intubation. Anesth Analg 1985; 64: 1211-3.

\section{Erratum - Cardiovascular and respiratory effects of ketamine in the neonatal lamb}

\section{To the Editor:}

I am writing to you to inform the readers of an error which appeared in our article ${ }^{\prime}$ in the January 1986 issue.

The doses of ketamine used in this study were reported incorrectly as $1 \mathrm{mg} \cdot \mathrm{kg}^{-1}$ and $2 \mathrm{mg} \cdot \mathrm{kg}^{-1}$. These were equivalent doses and the actual doses of ketamine used in the lambs were $15 \mathrm{mg} \cdot \mathrm{kg}^{-1}$, to be equivalent to $1 \mathrm{mg} \cdot \mathrm{kg}^{-1}$ in humans and $30 \mathrm{mg} \cdot \mathrm{kg}^{-1}$, to be equivalent to $2 \mathrm{mg} \cdot \mathrm{kg}^{-1}$. These doses were used because the dose requirements for ketamine in animals are higher than in man. ${ }^{2} \mathrm{We}$ apologize for this confusion.

\section{Frederick A. Burrows MD FRCPC \\ Department of Anaesthcsia \\ University of Toronto and \\ The Hospital for Sick Children \\ 555 University Avenue \\ Toronto, Ontario \\ M5G 1 X8}

\section{REFERENCES}

1 Burrows FA, Norton JB, Fewel J, Cardiovascular and respiratory effects of ketamine in the neonatal lamb. Can Anaesth Soc J 1986; 33: 10-5.

2 Booth NH. Intravenous and other parenteral anesthetics. In: Booth NH, McDonald LE (eds.) Veterinary Pharmacology and Therapeutics, 5th Edition. lowa State Liniversity Press, Ames, Iowa, 1982.

\section{Plasma cholinesterase activity following administration of glycopyrrolate or atropine}

To the Editor:

An in vitro study of the effects of glycopyrrolate and atropine on human plasma cholinesterase by Zsigmond et al. ${ }^{1}$ in this journal showed a moderate inhibitory effect on this enzyme with high concentraitons of both agents, with a theoretical possibility of an interaction with succinylcholine or ester-type local anaesthetics. It has since been pointed out that on pharmacological grounds only extremely large doses of glycopyrrolate, which are unlikely ever to be used in clinical practice, would produce such an inhibition of plasma cholinesterase activity in man. ${ }^{2} \mathrm{We}$ now report actual measurements of plasma cholinesterase 
activity in man following administration of glycopyrrolate or atropine.

Twenty-six adult patients of both sexes on no medication and without any medical disorder likely to affect plasma cholinesterase activity were studied after obtaining theis consent and the Hospital Ethical Committee's approval. No premedication was administered. The palients were divided into four groups, two receiving glycopyrolate $7.5 \mu \mathrm{g} \cdot \mathrm{kg}^{-1}$ IV (Group A, n = 7) or atropine $15 \mu \mathrm{g} \cdot \mathrm{kg}^{-1}$ (Group B, $\mathbf{n}=7$ ) prior to induction of anaesthesia and two receiving glycopyrtolate 10 $\mu \mathrm{gg}^{-1}$ (Group $\mathrm{C}, \mathrm{n}=6$ ) or atropine $20 \mu \mathrm{g} \cdot \mathrm{kg}^{-1}$ IV (Group D, $n=6$ ) prior to neostigmine administration for antagonism of nondepolarising neuromuscular block. Venous blood samples were taken before the anticholinergic drug administration and $\mathrm{I}, 2,5,10,20$ and 30 minutes later in groups $A$ and $B$ and $1,2,5,10$ and 15 minutes later but prior to the administration of neostigmine in groups $C$ and D. Plasma was separated within 30 minutes and cholinesterase activity was estimated using a colorimetric method $^{3}$ with butyrylthiocholine as the substrate. A $2 \mu$ l sample was diluted with $300 \mu \mathrm{l}$ of the reagent and was incubated for 120 seconds. Statistical analysis of the data was carried out using analysis of variance.

Plasma cholinesterase activity in the four groups is given in the Table. Analysis of variance showed that there was no significant difference in plasma cholinesterase activity in any group over the period of study.

Our results make it unlikely that routinely used doses of

TABLE Plasma cholinesterase activity $\left(1 . \mathrm{U} \cdot \mathrm{mL}^{-1}\right)$ following glycopyrrolate and atropine administration (mean \pm SD)

\begin{tabular}{|c|c|c|c|c|}
\hline $\begin{array}{l}\text { Minutes afier } \\
\text { drug admis. }\end{array}$ & 0 & 1 & 2 & 5 \\
\hline Group A & 5.65 & 5.49 & 5.41 & 5.51 \\
\hline$n=7$ & \pm 1.81 & \pm 1.86 & \pm 1.85 & \pm 1.78 \\
\hline Group B & 5.49 & 5.34 & 5.43 & 5.51 \\
\hline $\mathrm{n}=7$ & \pm 1.09 & $\pm 1 .(4)$ & \pm 0.96 & $\pm 1.0 \mathrm{l}$ \\
\hline Group C & 5.44 & 5.38 & 5.57 & 5.82 \\
\hline$n=6$ & $\pm] .43$ & \pm 1.11 & \pm 1.37 & \pm 1.45 \\
\hline Group D & 5.16 & 5.07 & 5.05 & 5.04 \\
\hline$n=6$ & \pm 1.03 & \pm 1.20 & \pm 1.28 & \pm 1.20 \\
\hline \multicolumn{5}{|l|}{ Minules offer } \\
\hline drug admin. & 10 & 15 & 20 & 30 \\
\hline Group A & 5,42 & & 5.31 & 5.34 \\
\hline$n=7$ & \pm 1.78 & & \pm 1.77 & \pm 1.80 \\
\hline Group B & 5.43 & & 5.40 & 5.34 \\
\hline$n=7$ & $=1.08$ & & \pm 1.05 & \pm 1.00 \\
\hline Group C & 5.52 & 5.79 & & \\
\hline$n=6$ & \pm 1.41 & \pm 1.39 & & \\
\hline Group D & 5.11 & 5.41 & & \\
\hline$n=6$ & \pm 1.21 & \pm 0.88 & & \\
\hline
\end{tabular}

slycopyrrolate or atropine have no clinically important effect on plasma cholinesterase activity. Interpolation made from the in vitro low anticholinesterase effect and minimal changes in plasma cholinesterase activity measured in man leads to the conclusion that either anticholinergic drug is unlikely to interfere with the hydrolysis of succinylcholine or ester-type local anaesthetics in patients.

\section{R.K. Mirakhur MD PHD FFARCS}

Department of Clinical Anassthesia

Royal Victoria Hospital

Belfast

Northem Ireland

C.I. Jones B PHARM MPS

A.H. Robins Co. Ltd.

Horsham, England

\section{REFERENCES}

I Zsigmond EK, Winnie AP, Barabas E, Wang XY. The inhibitary effect of glycopyrolate on human plasmacholinesterase. Can Anaesth Soc J 1985; 32: 20-2.

2 Mirakhur $R K$. Glycopymolate and human plasma cholinesterase. Can Anaesth Soc J 1985; 32: 683.

3 Ellman GL, Courtney KD, Andres VJ, Featherstone RM. A new and rapid colorimetric determination of acetylchol inesterase activity. Biochem Pharmacol 1961; 7: 88-95

\section{Percutaneous sheath introducer shaft-hub disconnection during pulmonary artery catheterization}

\section{To the Editor:}

We wish to report a recent problem which occurred during the insertion of a pulmonary artery catheter using an Arrow Percutaneous Sheath Introducer Set, SI-09800.

Our paticnt was a 29-year-old man weighing $90 \mathrm{~kg}$, scheduled for an elective aorto-coronary bypass graft. The right internal jugular vein was used for percutaneous cannulation by the Seldinger technique, and the catheter sheath inserted without difficulty and connected to the haemostasis valve with side port adapter. The balloontipped pulmonary artery catheter passed easily down the catheter sheath to approximately $25 \mathrm{~cm}$ at which time, while watching the monitor screen, the anaesthetist felt the separation of the shaft of the catheter sheath from the hub (Figure 1). As the anaesthetist was holding the shaft-hub junction, he was able to prevent the shaft from advancing into the neck. The hub and pulmonary artery 